\title{
Multi-scale analyses of subglacial and glaciomarine deposits from the Ross Sea continental shelf, Antarctica
}

\author{
S. J. Kluiving, ${ }^{1}$ L. R. Bartek, ${ }^{1}$ F. M. van der Wateren ${ }^{2}$ \\ ${ }^{1}$ Department of Geology, Box 870338, University of Alabama, Tuscaloosa, AL 35487-0338, U.S.A. \\ ${ }^{2}$ Netherlands Research School of Sedimentary Geology, Faculty of Earth Sciences, Vrije Universiteit, 1081 HVAmsterdam, The Netherlands
}

\begin{abstract}
Piston cores collected from the Ross Sea continental shelf, Antarctica, were studied as part of a multi-scale analysis of glacial and glaciomarine stratigraphy and sedimentology. The objective of these analyses was to differentiate glaciomarine sediments from subglacially deformed tills. Results from analyses of microstructures, lithofacies and seafloor morphology indicate that glaciomarine and subglacially deformed sediments can be clearly distinguished and further characterized by variations in textural parameters. Overcompaction, as well as presence of stratification in sediments, are not considered critical criteria for distinguishing subglacial from glaciomarine deposits. Trough-shaped morphologies and fluted terrain strongly correlate with S-C and S-C-C'type shear-zone microstructures and indicate that subglacial deformation is an important process in these areas, confirming the presence of grounded ice on the shelf during formation of these landforms and deposits. Flat, smooth topographies, as well as (low-angle) slope environments, correspond to microfabrics which lack microscopic shear-zone geometries and contain dropstones, angular-sediment clasts, large-shell fragments and slight sorting in sandy layers, which imply ice-shelf or open-water conditions present during deposition.
\end{abstract}

\section{INTRODUCTION}

Seismic data have provided compelling evidence for multiple glaciations on the Ross Sea continental shelf, Antarctica since at least the Oligocene until the present (Alonso and others, 1992; Anderson and Bartek, 1992; Bartek and others, 1997). The evidence includes a foredeepened continental shelf, large-scale glacial troughs (comparable in size to modern-day ice streams) and a distinctive variation in seismic facies, indicating an alternation of glaciomarine (i.e. ice shelf) and grounded ice-sheet conditions.

Cenozoic sediments from the Ross Sea continental margin have been studied by different authors for a number of decades (e.g. Barrett, 1975; Anderson, 1991). Deep Sea Drilling Project (DSDP) drill holes (sites 270 to 273), drilled in the 1970s, have provided limited information due to poor core recovery, and the limited geographical distribution of the cores, relative to the large area of the Ross Sea continental shelf. However, the data from the DSDP drill sites are quite valuable when correlated to high-resolution seismic data.

Deformation of the glacier bed plays a key role in the dynamics of mid-latitude ice sheets (Boulton, 1979; Boulton and Jones, 1979; Boulton and Hindmarsh, 1987). Compressive flow occurs within a narrow marginal zone, while extending flow occurs further upstream (Boulton, 1996). Sediments may be eroded by subglacial shearing from the region of extending flow and transported towards the margin, creating a subglacial shear zone and a marginal compressive belt (van der Wateren, 1995b, c). Strain rates in saturated sediment beneath a temperate glacier have been recorded in the order of $10 \mathrm{a}^{-1}$ (Boulton, 1996; Boulton and Hindmarsh, 1987). Within a geologically very short time period, this results in extremely high shear strains in the subglacial shear zone. Analysis of microstructures of subglacial shear zones in samples from drill cores provides a method by which it is possible to determine the location of a glacial grounding line across the continental shelf (Van der Wateren, 1995a).

Overconsolidated marine sediments have been related to the presence of grounded ice on the Ross Sea continental shelf (e.g. Anderson and others, 1980; Corradi and others, 1997) on the assumption that they were loaded by the weight of the overlying glacier during their deposition. In contrast, glaciomarine sediments deposited beneath floating ice are considered normally consolidated (Kurtz and others, 1979). Data presented in this paper show that subglacially deformed tills need not necessarily be overconsolidated and that these geotechnical properties are not diagnostic for distinguishing subglacial from glaciomarine diamictons.

The subject of this study is 14 piston cores, located in the central and eastern part of the Ross Sea continental shelf (Fig. 1). The cores were all collected during the NBP 94-07 cruise in the austral summer of 1994-95. During the cruise, a total of 93 piston cores were acquired with core lengths ranging from $0.2 \mathrm{~m}$ to $>4 \mathrm{~m}$. All cores were located on high-resolution seismic lines so samples of underlying seismic facies could be obtained (Bartek and others, 1997).

In this paper we demonstrate the use of microfabric analysis of cored sediments (15 samples), integrated with seafloor morphology (swath bathymetry and multibeam) and lithofacies to assist in distinguishing glacial marine from subglacial deposits. The aim of this study is to deter- 


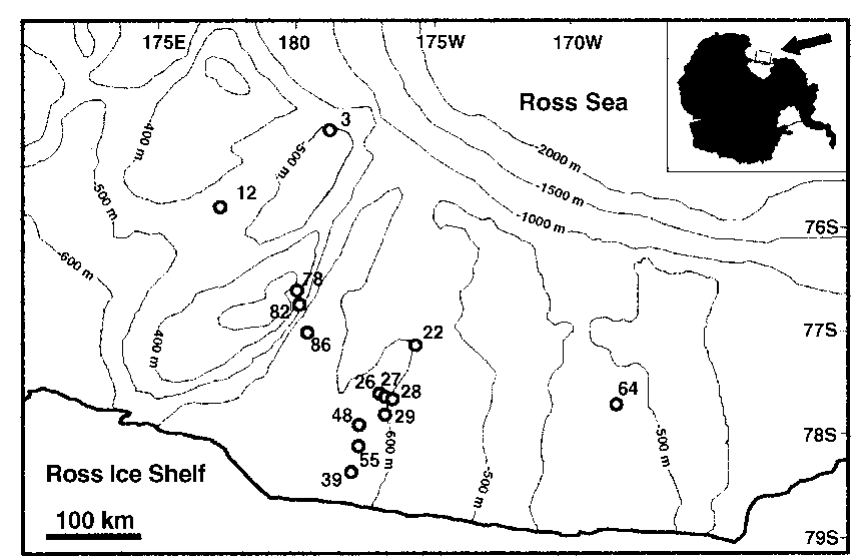

Fig. 1. Central and eastern Ross Sea with bathymetry of continental shelf and location of piston cores. Inset shows location in Antarctica.

mine which depositional environments are represented by the Cenozoic sediments of the Ross Sea continental shelf and to establish the relationship between lithofacies and large-scale glacial events.

\section{METHODS}

To distinguish subglacial and glaciomarine deposits, an analysis of data at multiple scales is used. Chirp-sonar data are acquired and used to map variation in subbottom stratigraphy. Piston cores are collected from landforms identified with chirp sonar, to obtain lithofacies data and samples for microscopic analysis associated with the landforms and cored deposits.

The term microfabric, used in this study, is defined as the relative orientation of parts of a rock mass, which refers to all components contained in a rock (Passchier and Trouw, 1996, p. 258). The method of structural analysis used here differs from micromorphology, a method originally developed in soil science which has been applied succesfully in glacial geology (Van der Meer, 1993, 1996; Hiemstra and Van der Meer, 1997). Because of the great similarity of (micro) structures produced by subglacial deformation in subglacial tills and deformation found in metamorphic rocks (Van der Wateren, 1995b, in press), we present a classification commonly used in structural geology as an alternative. Microstructural analysis involves a morphological classification and kinematic analysis of foliations, as well as identification of S-C and S-C-C'-type shear-zone geometries, quite similar to that observed in mylonites, for example (Passchier and Trouw, 1996). Fabric strength is related to the magnitude of the finite strain: high shear strains result in a strong shearzone fabric; low shear strains result in a weak fabric. Strength of the fabric also depends on the rheology and/or carbonate content of the material; therefore we compare the strengths of fabrics in relation to our observations on other scales, i.e. from the core lithologies to the chirp-sonar profiles, and make our interpretations based on this multi-scale analysis.

Piston cores are X-rayed and split lengthwise in the laboratory. Geotechnical properties, including shear strength and penetration (unconfined strength) are measured using a Torvane with three sizes of vanes and a pocket penetrometer. All measurements were conducted at $0.1 \mathrm{~m}$ intervals. Standard lithological descriptions (Janecek, 1995) are made of the cores and their X-radiographs to document downcore variations in macroscopic sedimentary structures, pebble characteristics (content, size, and roundness), sediment clasts, the association of sedimentary contacts and the macrofossil content. Grain-size distribution is analyzed using an automated settling tube (of similar design to that of Anderson and Kurtz, 1979) and a laser particle-size counter (Spectrex) for the sand and silt-clay fractions, respectively. Organic carbon determinations were measured by combustion of a dehydrated sample at $500^{\circ} \mathrm{C}$ (Froehlich, 1980).

Samples for microscopic analyses were selected on criteria, such as lithofacies, geotechnical properties, seismic facies, location and age. Each sample was collected from the core as blocks ranging $0.5-0.1 \mathrm{~m}$ in length. The samples were air-dried in the laboratory for 2-4 weeks, impregnated, cut, mounted on glass slides varying from $60 \times 60$ to $60 \times 90 \mathrm{~mm}$ and polished to a thickness of about $20 \mu \mathrm{m}$ (Maltman, 1994; Van der Meer, 1993, 1996).

\section{RESULTS}

Results of microfabric analysis, along with their associated lithofacies and the piston core's location on $3.5 \mathrm{kHz}$ (chirp) profiles, indicates the presence of two groups (Table 1): Group 1 (eight piston cores) is found in troughs or on a ridge and swale topography, muddy diamicton composition and with microfabrics that show S-C and S-C-C'-type shearzone geometries, providing evidence of strong shearing along ductile shear zones. Group 2 (six piston cores), situated on slopes and flat terrain, consists of various lithologies which contain microfabrics with attributes such as dropstones, angular-sediment clasts, large shell fragments and slight sorting in sandy layers, lacking a distinctive shearzone geometry. Analytical results of textural, geotechnical and organic matter are presented next.

\section{Microstructures, lithofacies, chirp sonar}

\section{Group 1}

Cores NBP94-7-48PC and -86PC are both located in areas of ridge and swale topography (ridge height, $10-20 \mathrm{~m}$; ridgeridge spacing, 100-500 m) (Table 1, Fig. 2 ). At the macroscopic scale, core 86PC contains a massive muddy diamict (contains $>70 \%$ mud) and core $48 \mathrm{PC}$ contains $0.2 \mathrm{~m}$ of alternating bands of sand and mud. Microfabric analysis shows that core 86PC has a well-developed continuous $\mathrm{S}$ cleavage cut by spaced $\mathrm{C}^{\prime}$ planes, as well as clasts with a rotational fabric within the matrix surrounding the clasts. Core 48PC shows a well-developed shear-band cleavage; S$\mathrm{C}$ cleavage cut by $\mathrm{C}^{\prime}$ planes (Fig. 3).

Piston cores NBP94-7-26PC, -27PC and -28PC are found on the upper and lower flank of a shallow trough (flank horizontal dimension approximately $500 \mathrm{~m}$ ) and in the center of the shallow trough, respectively. The trough is approximately $12 \mathrm{~km}$ wide and $20 \mathrm{~m}$ deep (Fig. 4). Cores 27PG and 28PC are composed primarily of muddy diamicton with silty lenses and/or layers of sandy mud, while core 26PC contains a massive muddy diamict. The microfabric of a sample from core 28PC shows a clear S-C-C' shear-zone fabric (cf. Fig. 3). Core 27PG shows a continuous, strong cleavage in a silty layer attributed to stretching and an Scleavage sigmoidally shaped between the subhorizontal spaced C-cleavages, which is interpreted as a dextral S-C shear-zone fabric (Fig. 4). Core 26PC shows a weaker fabric strength compared to $27 \mathrm{PC}$ and $28 \mathrm{PC}$, with a single pene- 
Table 1. Results of microfabric characteristics, lithofacies from piston cores, seafloor morphology, geotechnical measurements and organic-matter content

\begin{tabular}{|c|c|c|c|c|c|c|c|c|c|c|}
\hline \multirow[t]{2}{*}{$\begin{array}{l}\text { Piston } \\
\text { core no. }\end{array}$} & $\begin{array}{l}\text { Water } \\
\text { depth }\end{array}$ & $\begin{array}{l}\text { Core } \\
\text { length }\end{array}$ & $\begin{array}{l}\text { Depth micro- } \\
\text { fabric sample }\end{array}$ & $\begin{array}{c}\text { Microfabric } \\
\text { characteristics } \\
f .=\text { fabric }\end{array}$ & $\begin{array}{l}\text { Sedimentary } \\
\text { structures } \\
\text { unit sample }\end{array}$ & Lithology & $\begin{array}{l}\text { Seafloor morphology from } \\
3.5 \mathrm{kHz} \text { (Chirp-sonar) } \\
\text { profiles, slope angles in degrees }\end{array}$ & $\begin{array}{l}\text { Shear } \\
\text { strength }\end{array}$ & $\begin{array}{l}\text { Unconf. } \\
\text { strength }\end{array}$ & $\begin{array}{c}\text { Organic } \\
\text { matter }\end{array}$ \\
\hline & $\mathrm{m}$ & $\mathrm{m}$ & $\mathrm{m}$ & & & & $\circ$ & $\mathrm{kg} \mathrm{cm}^{-2}$ & $\mathrm{~kg} \mathrm{~cm}^{-2}$ & $\%$ \\
\hline \multicolumn{11}{|l|}{ Group 1} \\
\hline 26 & 624 & 3.64 & $3.10-3.15$ & ? S cleavage & L3 & Mud D & Trough, upper flank & 0.20 & 0.22 & 0.49 \\
\hline 27 & 626 & 2.89 & $0.94-0.99$ & SC shear z. & $\mathrm{Ll}, 2,3 \mathrm{cdl}$ & Mud D & Trough, lower flank & 0.19 & 0.12 & 0.59 \\
\hline 28 & 644 & 2.14 & $1.89-1.98$ & $\mathrm{SCC}^{\prime}$ sh.z. & $\mathrm{H} \mathrm{cdl}$ & Mud D & Trough ( $12.3 \mathrm{~km}$ wide), center & 0.35 & 0.20 & 0.67 \\
\hline 48 & 670 & 0.20 & $0.12-0.20$ & $\mathrm{SCC}^{\prime}$ sh.z. & $\mathrm{L} 1,2 \mathrm{cdl}$ & Sand-mud & Ridge-and-swale topography & - & - & 0.48 \\
\hline 29I & 628 & 3.23 & $2.00-2.07$ & SG sh.zone & $\mathrm{L} 3,4 \mathrm{c}$ & Mud D & (no $3.5 \mathrm{kHz}$ data available) & 0.45 & 0.04 & 0.50 \\
\hline 29II & 628 & & $3.03-3.11$ & SC sh.z. & $\mathrm{L} 3,4 \mathrm{c}$ & Mud D & & 0.48 & 0.05 & - \\
\hline 39 & 693 & 1.03 & $0.66-0.72$ & $\mathrm{SCC}^{\prime}$ sh.z. & $\mathrm{L} 1,3,4 \mathrm{c}$ & Silt D & Trough (35-40 km wide) & 0.22 & 0.08 & 0.51 \\
\hline 64 & 568 & 1.51 & $1.29-1.36$ & $\mathrm{SCC}^{\prime}$ sh.z. & $\mathrm{L} 3,4 \mathrm{c}$ & Mud D & Trough $(7.5 \mathrm{~km}$ wide $)$ & 0.14 & 0.11 & 0.64 \\
\hline 86 & 706 & 1.59 & $1.43-1.49$ & $\mathrm{SC}^{\prime}$ sh.zone & $\mathrm{L} 4 \mathrm{c}$ & Mud D & Ridge-and-swale topography & 0.20 & 0.14 & 0.59 \\
\hline \multicolumn{11}{|l|}{ Group 2} \\
\hline 3 & 551 & 2.86 & $0.24-0.29$ & Irreg. clasts & $\mathrm{L} 1,3,4 \mathrm{cl}$ & Silt D & Flat, slightly undulating, smooth & 0.16 & 0.15 & 0.55 \\
\hline 12 & 447 & 2.13 & $2.00-2.06$ & Dropstone f. & $\mathrm{L} 3,4 \mathrm{cdl}$ & Silt D & Flat, irregular rugged topography & 0.42 & 0.70 & 0.82 \\
\hline 22 & 615 & 3.47 & $1.72-1.77$ & Rotational f. & $\mathrm{H} \mathrm{c}$ & Sandy silt D & Slope $\left(0.2^{\circ}\right)$, slightly undulating, smooth & 0.07 & 0.04 & 0.58 \\
\hline 55 & 687 & 3.12 & $2.91-2.97$ & Angular clast & $\mathrm{Hc}$ & Silt & Flat, smooth & 0.15 & 0.08 & 0.55 \\
\hline 78 & 357 & 2.70 & $1.83-1.89$ & Forams,spic. & $\mathrm{Ll}, 4 \mathrm{c}$ & Sand & Slope $\left(3^{\circ}\right)$, large-scale bumps & 0.29 & 1.75 & 0.45 \\
\hline 82 & 453 & 2.42 & $2.04-2.09$ & Weak f. & L3 c & Mud D & Slope $\left(5^{\circ}\right)$, slightly undulating, smooth & 0.16 & 0.11 & 0.52 \\
\hline
\end{tabular}

Notes: L1 - layering by grain-size differences; L2 - layering by color differences; L3 - layering by variation in gravel density; L4-layering by gray-scale differences from X-ray; $\mathrm{H}$ - homogeneous, no apparent layering; $\mathrm{c}$-soft-sediment clasts; $\mathrm{d}$-discontinuous laminae; 1 - continuous laminae.

trative cleavage and weak rotational fabrics in the matrix around sand grains.

Similar trough morphologies are associated with cores NBP94-7-39PG and -64PC, although different in size (35$40 \mathrm{~km}$ wide and 50-75 $\mathrm{m}$ deep for the trough with core 39PC and $9 \mathrm{~km}$ wide and 15-20 m deep for the trough with core $64 \mathrm{PG}$ ). The cores contain muddy diamictons and both show $\mathrm{S}-\mathrm{C}-\mathrm{C}^{\prime}$ shear-zone fabrics in very strong birefringent matrices at the microscopic level.

Lithologies of the group 1 samples are generally muddy diamictons. Lithofacies of the intervals sampled for microfabric analyses of group 1 strata vary, but generally show some sort of layering (L1, 2, 3, 4; see Table 1). Layers (L3) of variable densities of fine to very fine pebbles $(2-8 \mathrm{~mm})$ in macroscopically observed homogeneous diamictons are relatively common. This stratification is commonly on the order of $0.1-0.5 \mathrm{~m}$, but also shows as bands up to $1.5 \mathrm{~m}$ and

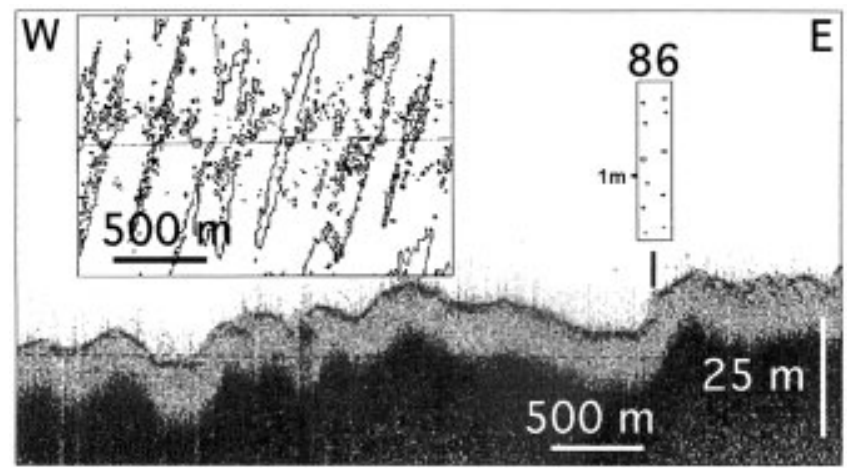

Fig. 2. Chirp-sonar profile showing ridge and swale topography and location of core NBP94-7-86. Core symbols indicate pebbles. Inset shows contours of ridges with consistent NNE-SSW orientations; contour interval $10 \mathrm{~m}$. is observed in X-radiographs. Continuous to discontinuous laminae and clasts are also common within group 1 samples.

\section{Group 2}

Core NBP94-7-55PG contains a massive silt unit (>70\% silt) and was acquired from a site located on a flat, smooth surface (Fig. 5). The microfabric analyses indicate a lack of cleavage or any shear-zone fabric and shows there are abundant small to large $(<32 \mathrm{~mm})$ unlithified mud clasts with angular shapes (Fig. 5).

A slightly undulating sea-bed morphology is associated with cores NBP94-7-3PC and -12PG (Table 1). Both contain silty diamictons $(<70 \%$ silt) and show a laminated structure. Microfabric analysis fails to reveal any distinctive cleavage, but reveals dropstone fabrics of coarse pebbles (underlying layer shows depression at the contact), wavy contacts, discontinuous sand layers, irregularly shaped clasts and alternating laminations of diatom and foram muds.

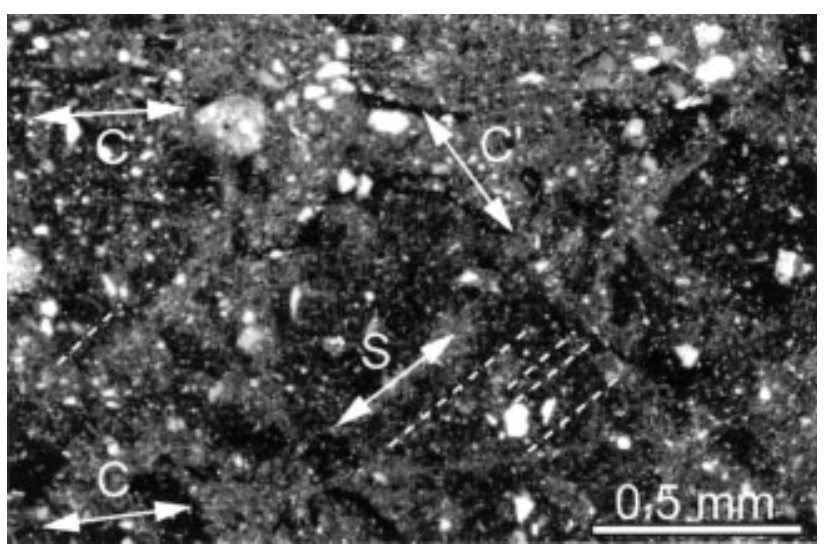

Fig. 3. Microfabric of sample from core NBP94-7-48: $S-C-C^{\prime}$ shear zone, with crossed polarizers and gypsum plate. 


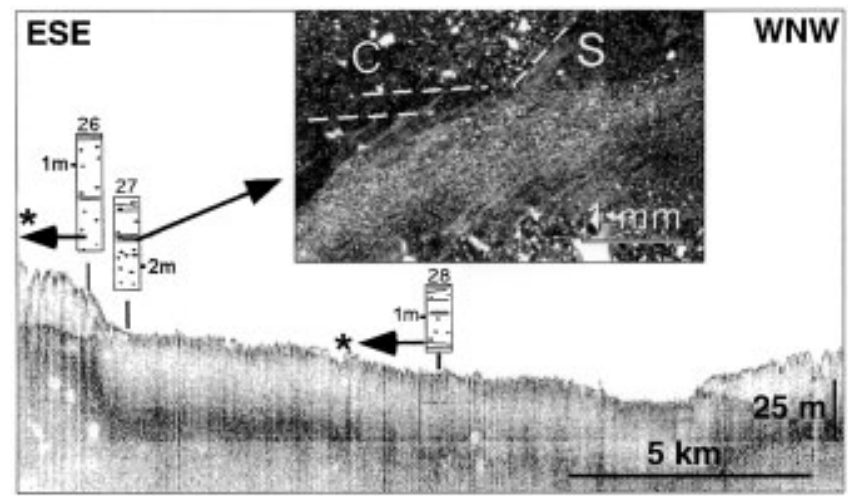

Fig. 4. Chirp-sonar profile showing trough morphology and location of cores NBP94-7-26, -27 and -28. Symbols indicate pebbles and horizontal contacts, as well as laminae. Inset shows microfabric of NBP94-7-27, S-C shear zone in silt band, with crossed polarizers.

Core NBP94-7-78PC is on an undulating large-scale $3^{\circ}$ slope (Fig. 6). The core is a sequence of alternating sand and muddy sand with abundant large to very large-sized mud clasts. The sand contains abundant forams, spicules and diatoms (Fig. 6).

Cores NBP94-7-22PC and -82PC are also associated with slope locations and contain muddy and silty diamictons, respectively (Table 1). Multi-beam data in the vicinity of core 82 show slope fans, probably indicative of sediment gravity-flow processes. The microfabric of core $82 \mathrm{PC}$ also lacks any distinctive cleavage and/or asymmetric shear-zone structure. On the microscopic scale, the matrix of core 22PG appears to comprise folded lamina, often in irregular and isolated forms. Sediment clasts of different colors and composition are found throughout the sample. Some sediment clasts, as well as most sand grains, possess a rotational fabric in the clay matrix around them.

Lithofacies descriptions of the units from which the microfabric samples were taken are variable. Sedimentary structures in group 2 generally indicate a layering of some sort $(\mathrm{L} 1,3,4)$ or the absence of layering ( $\mathrm{H}$, homogeneous). Clasts are common, as well as (dis)continuous lamina within the layered intervals. The lithologies of the samples in this

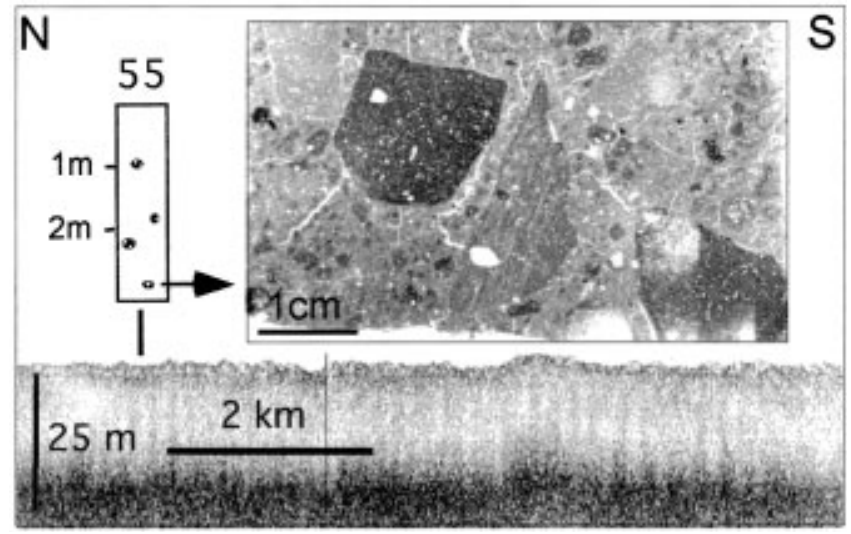

Fig. 5. Chirp-sonar profile showing flat smooth topography at core NBP94-7-55. Symbols indicate soft-sediment clasts. Inset showes microfabric with prominant angular shape of sediment clasts. View with plane light.

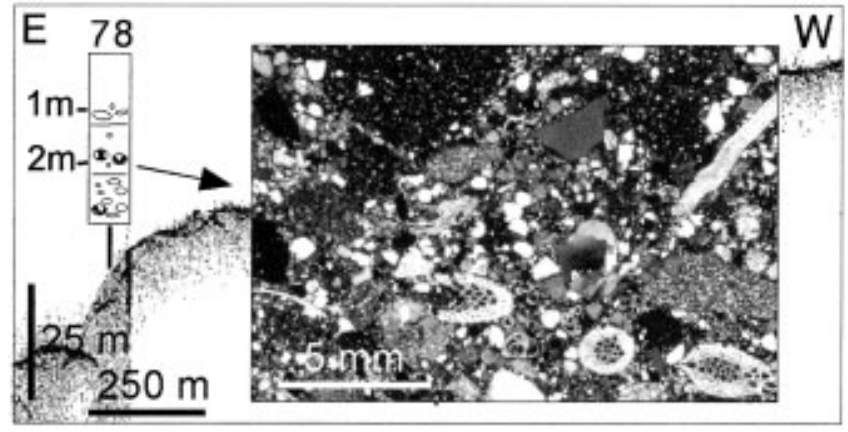

Fig. 6. Chirp-sonar profile showing slope with undulating topography at core NBP94-7-78PC. Rugged topography may be indicative of mass movement. Symbols show pebbles, as well as soft-sediment clasts. Inset shows microfabric with abundant foraminifera; in upper part, an angular coarsesized mud clast is seen. View with crossed polarizers.

group range from sand and muddy sand to silt to muddy and silty diamictons.

\section{Textural analysis, geotechnical measurements, organic-matter content}

The two groups (Table 1) distinguished on basis of their microfabric, lithofacies characteristics and bottom morphology, as identified in chirp sonar data, are also recognized in analyses of sediment texture (Fig. 7). It appears the sediments of group 1 are almost exclusively mud diamictons and are very poorly sorted. Kurtosis descriptions of the curves vary from platykurtic, mesokurtic, to very leptokurtic, and the distributions can be described as polymodal .The majority of grain-size curves in group 1 are negatively skewed, due to a slightly higher sand and gravel content (Fig. 7a). Group

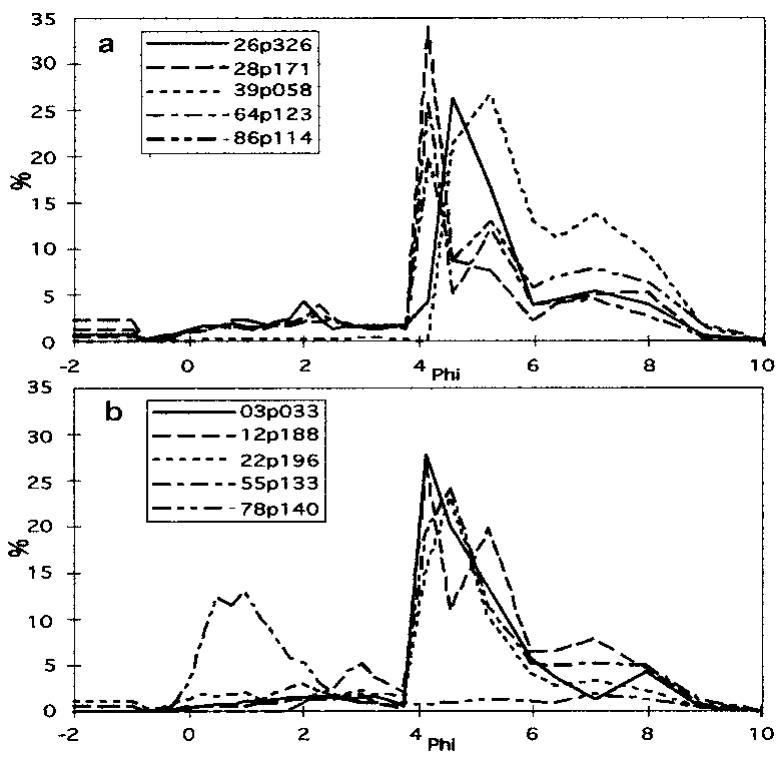

Fig. 7. Particle-size analysis with frequency-distribution curves of sediment samples from cores of group 1 ( a) and group 2 (b). Group 1 shows generally polymodal, very poorly sorted, platy-, meso- to leptokurtic curves, whereas group 2 exhibits unimodal, poorly sorted, leptokurtic distributions. The first two digits refer to the core number, the last three digits refer to the depth (in cm) of sample. 
2 sediments, on the other hand, show more variety in their lithologies and are slightly better sorted (poorly) than group 1 sediments. Kurtosis in group 2 can be described as almost exclusively leptokurtic, distributions are almost unimodal and most curves are positive to symmetrically skewed (Fig. 7b).

Shear-strength values in group 1 samples are slightly higher than in group 2 (average values $0.28-0.21$ ), but the unconfined strength values are higher in group 2 sediments (0.12-0.59) (Table 1). Analysis-of-variance of the shear strength and unconfined strength of the two groups indicates there is a low probability of the shear strength or the unconfined strength values of samples from the two groups being significantly different $(P=.33$ and .16$)$.

Diatomaceous muds and oozes may contain high concentrations of organic (bituminous) compounds. This organic matter is expected to mask birefringence patterns in the clays, which could make it impossible to identify shearzone fabrics. The results of the loss-of-ignition test on the samples shows there is no significant difference in organicmatter content between the two groups (Table 1) $(P=.83$ ). So the masking effect described above can be ignored for the set of cores described in this paper.

\section{DISGUSSION}

Sediments from group 1 can be correlated to a seafloor morphology of a ridge and swale topography or to small- and large-scale troughs. Spacing between ridges occurs on a $100 \mathrm{~m}$ scale, while trough widths occur on a $\mathrm{km}$ scale.

Since cores NBP94-7-86PC and -48PC exhibit shearzone fabrics (S-C' and S-C-C' type, Fig. 3) and both are located on a lineated topography, the microfabric is interpreted as suggesting subglacial shearing as the process responsible for both the homogeneous diamict (core -86PG) and the laminated mud (core-48PG) (Fig. 2).

Erosional scours and valleys are well known and described from the Ross Sea continental margin (e.g. Anderson and others, 1992). The shear-zone assymetry represented in the microfabrics of cores NBP94-7-27PG and 28PG are interpreted as representing strong subglacial shearing. The position of the cores -27 and -28PC inside the trough conforms with the subglacial interpretation of the shear-zone fabrics and suggests subglacial erosion by grounded ice as the mechanism responsible for the trough morphology (Fig. 4). The weak fabric strength of the microfabric of NBP94-7-26PC, makes its interpretation less conclusive. The evidence from core -26PG, located on the upper flank of the trough, may suggest less-powerful subglacial deformation outside the trough (Fig. 4).

At the microscopic level, cores NBP39PC and -64PG show S-C-C' shear-zone fabrics in very strong birefringent matrices, indicative of subglacial deformation of the bed as the ice was moving over the continental shelf. The position of both cores in troughs suggests that subglacial erosion may also have eroded these sites. One trough, containing core 39PC, has dimensions comparable to modern-day ice streams. The combination of these observations lends strong support to the hypothesis that the process of subglacial erosion and deformation is responsible for the trough morphology, as well as till formation.

Although the lithofacies descriptions vary considerably for each core within group 1 ranging from homogeneous to layered, the fine and very fine pebble-density variation (L3), as well as the dominant mud-diamicton lithology, seem to be common features within this group (Table 1). Possibly the pebble-density variation reflects an intermediate stage of mixing sediment layers in a deformable bed, prior to total homogenization. The pebble-density variations, as well as the presence of discontinuous and continuous lamina in many of the cores and samples and associated with S-C, S- $\mathrm{C}^{\prime}$ and S-C-C' fabrics, can be explained as a "transposed sedimentary foliation" (Van der Wateren, 1995c). A "transposed sedimentary foliation" can be a diamict with a diffuse compositional layering which is the product of intense shearing.

Group 2 sediments are found on low-angle slopes and on flat, smooth terrain. Core NBP94-7-55PC is associated with such flat terrain (Fig. 5). The well-preserved angular facets of the soft-sediment clasts suggest deposition with minimal clast-to-clast contact, such as settling through a water column, and excludes a subglacial deformation process which produces rounded clasts (Van der Meer, 1993, 1996).

Observations from cores NBP94-7-3PG and -12PC on a microscale show dropstone fabrics, wavy contacts, discontinuous lamina and irregular-shaped clasts in the absence of a shear-zone fabric. The association of these microfabric characteristics with a smooth, slightly undulating topography, suggests settling from suspension from underneath an iceberg or ice shelf, with minor sediment gravity-flow.

The position on a slope of core NBP94-7-78PC (Fig. 6) and the possibility that the undulations are slump"mounds", may suggest that the mixed sand-muddy sand facies in this core is produced by a sediment gravity-flow.

Cores NBP94-7-82PG and -22PG are both located on slopes. NBP94-7-82PC, as seen on chirp-sonar profile as well as multi-beam, is associated with a slope-fan morphology. The lack of any cleavage or shear zone in the microfabric analysis associated with this morphology suggests an environment characterized by slump processes. Rotational fabric is generally considered as evidence for rotational movement and subglacial deformation within a sediment mass (skelsepic plasmic fabric: Van der Meer, 1993). The rotational fabric of NBP94-7-22PG associated with vague folded matrix bands, in absence of any shear-zone fabric and related to the core's position on a slightly undulating slope, is interpreted here as a lower grade of soft-sediment deformation, possibly a product of a debris flow in a glaciomarine environment.

Lithofacies analysis of group 2 sediments reveals no common structure (Table 1); homogeneous and layered structures are both common. Lithologies vary from sand to silt, indicating variable sources of sediment or variable processes of sediment transport and sorting of sediments, such as sediment gravity-flows and "rain-out" (ice-rafted debris) processes.

Comparisons of textural parameters such as skewness, kurtosis and sorting of group 1 and group 2 samples indicate that the texture of the samples from the two groups are different (Fig. 7). Group 1 samples are negatively skewed, while group 2 samples are symetrically to positively skewed and tend to be better sorted and have a leptokurtic grain-size distribution. These features imply that group 2 sediments primarily have a unimodal distribution suggesting that a single process or source is responsible for deposition, whereas group 1 samples have variable, more multimodal distributions suggesting multiple sources or multiple processes, mixing or reworking of the sediments. The latter processes correlated to texture are consistent with processes associated with a deformation till (Boulton, 1996; Van der Wateren, 1995b). The 
more leptokurtic distribution and better sorting of group 2 samples may be attributed to winnowing of sediment by currents as the sediment settles through the water column. The effects of the presence of sediment clasts on the grain-size distribution is not considered here, because the distribution of clasts within the sediment of each group is equal.

Early research involving detailed analysis of diamictons in the Ross Sea formulated criteria which favored a subglacial origin for the diamictons (Kellogg and others, 1979; Anderson and others, 1980). Some of these criteria include a lack of sorting and stratification, absence of fossils, as well as overcompaction, as indicative for a subglacial origin. However, Anderson and others (1992) stated that caution should be exercised when using these criteria for environment depositional interpretation and suggested that these criteria were not conclusive indicators of subglacial deposition. In this study, both groups 1 and 2 show layered and laminated structures in their cores (see Table l) and therefore the groups cannot be easily distinguished from one another based on the presence or absence of macroscopic stratification. Also, the geotechnical measurements performed on the cores cannot be used for differentiating the sediments into two groups in the same manner as is demonstrated by the integration of microfabric analyses, lithofacies, chirp data and textural analyses. Therefore, a multi-scale analysis is best for differentiating subglacial from glaciomarine environments. Use of single or even combined criteria as stratification and/or overcompaction can give erroneous interpretations of depositional environments and should therefore be avoided.

\section{CONCLUSIONS}

Analysis of microfabrics in samples from piston cores, along with seafloor morphologies, textural data and lithofacies characteristics, is a strong tool to distinguish subglacial tills from glaciomarine deposits on high-latitude continental margins.

Ice sheets or ice streams, grounded on the continental shelf may erode trough-shaped morphologies and/or may leave a fluted terrain imprinted on the soft-sediment substrate (Figs 2 and 4). Sediments deformed by overriding ice share a similar lithofacies and show as rather homogeneous mud diamictons. The outcome of the textural analysis suggests that these coarse-skewed, very poorly sorted sediments may have been reworked and mixed multiple times. On a microscale, S-C and S-C-C'-type shear-zone geometries indicating subglacial deformation confirm the presence of grounded ice on the shelf during formation of this deposit.

Ice shelves and icebergs produce sediment via meltout at their base and glaciomarine deposition results in flat, generally smooth topographies, or deposition is on slopes where sediment gravity-flows may modify the sediment. Glaciomarine deposits are poorly sorted with symmetrical curves, show more variety in lithologies and the kurtosis-parameter suggests a single depositional process is responsible for the grain-size distribution. Microfabrics and composition associated with group 2 sediments include: abundant forams; dropstone fabrics around pebbles; angular clasts and irregular-clast shapes; and folded and mixed nature of the matrix, associated with rotational fabrics around sand and silt grains. There is an absence of a shear-zone fabric characteristic. The results of the microfabric analysis, combined with the textural, lithofacies and sea-floor data provide evidence for glaciomarine depositional processes, ranging from set- tling-from-suspension to sediment gravity-flows as being most important in formation of group 2 deposits. This implies ice shelf or open-water conditions present on the continental shelf during the deposition of these sediments.

\section{ACKNOWLEDGEMENTS}

This research was supported by U.S. National Science Foundation grants OPP-9220848 and OPP-9316710. We thank the captain and crew of the R/V Nathaniel B. Palmer, as well as the technicians of the Antarctic Support Associates for their help and support during the cruises. F. M. van der Wateren acknowledges support from the Netherlands Geosciences Foundation, with financial aid from the Netherlands Organization for Scientific Research. We thank J. van der Meer, J. Rose, and A. Stroeven for critical reviews of the paper which resulted in substantial improvements to the text. N. Koot of the Rock Processing Laboratory, Vrije Universiteit Amsterdam, is thanked for her skillful preparation of the thin sections.

\section{REFERENCES}

Alonso, B., J. B. Anderson, J. I. Diaz and L. R. Bartek. 1992. Pliocene-Pleistocene seismic stratigraphy of the Ross Sea: evidence for multiple ice sheet grounding episodes. In Elliot, D. H., ed. Contributions to Antarctic research III. Washington, DC, American Geophysical Union, 93-103. (Antarctic Research Series 57.)

Anderson, J. B. 1991. The Antarctic continental shelf: results from marine geological and geophysical investigations. In Tingley, R. J., ed. The geology of Antarctica. Oxford, etc., Clarendon Press, 285-334. (Oxford Monographs on Geology and Geophysics 17.)

Anderson, J. B. and L. R. Bartek. 1992. Cenozoic glacial history of the Ross Sea revealed by intermediate resolution seismic reflection data combined with drill site information. In Kennett, J. P. and D. A. Warnke, eds. The Antarctic paleoenvironment: a perspective on global change, Part 1 . Washington, DC, American Geophysical Union, 231-263. (Antarctic Research Series 56.)

Anderson, J. B. and D. D. Kurtz. 1979. "RUASA"; an automated rapid sediment analyser. F. Sediment. Petrol., 49(2), 625-627.

Anderson, J. B., D. D. Kurtz, E. W. Domack and K. M. Balshaw. 1980. Glacial and glacial marine sediments of the Antarctic continental shelf. f. Geol., 88 4 (4), 399-414.

Anderson, J. B., S. S. Shipp, L. R. Bartek and D. E. Reid. 1992. Evidence for a grounded ice sheet on the Ross Sea continental shelf during the Late Pleistocene and preliminary paleodrainage reconstruction. In Elliot, D. H., ed. Contributions to Antarctic research III. Washington, DG, American Geophysical Union, 39-62. (Antarctic Research Series 57.)

Barrett, P. J. 1975. Textural characteristics of Cenozoic preglacial and glacial sediments at Site 270, Ross Sea, Antarctica. Deep Sea Drilling Project. Initial Reports, 28, 757-767.

Bartek, L. R., J. L. R. Andersen and T. A. Oneacre. 1997. Substrate control on distribution of subglacial and glaciomarine seismic facies based on stochastic models of glacial seismic facies deposition on the Ross Sea continental margin. Mar. Geol., 143, 223-262.

Boulton, G. S. 1979. Processes of glacier erosion on different substrata. F. Glaciol., 23(89), 15-38.

Boulton, G. S. 1996. The origin of till sequences by subglacial sediment deformation beneath mid-latitude ice sheets. Ann. Glaciol., 22, 75-84.

Boulton, G. S. and R. C. A. Hindmarsh. 1987. Sediment deformation beneath glaciers: rheology and geological consequences. f. Geophys. Res., 92(B9), 9059-9082.

Boulton, G. S. and A. S. Jones. 1979. Stability of temperate ice caps and ice sheets resting on beds of deformable sediment. F. Glaciol., 24(90), 29-43.

Corradi, N., G. Fierro, L. Mirabile, M. Ferrari and R. Ivaldi. 1997. Geotechnical, sedimentological characteristics and seismic stratigraphy of northern Joides Basin (Ross Sea, Antarctica): preliminary results. In Ricci, C. A., ed. The Antarctic region: geological evolution and processes. Siena, Terra Antarctica Publication, 885-888.

Froelich, P. N. 1980. Analyses of organic carbon in marine sediments. Limnol. Oceanogr., 25(3), 564-572.

Hiemstra, J. F. and J. J. M. van der Meer. 1997. Pore-water controlled grain 
fracturing as indicator for subglacial shearing in tills. f. Glaciol., 43(145), 446-454.

Janecek, R., ed.. 1995. Sediment descriptions of $R / V$ Nathaniel B. Palmer cruise 8 1993. Tallahassee, FL, Florida State University. Antarctic Marine Geology Research Facility. (Contribution 3.)

Kellogg, T. B., R. S. Truesdale and L. E. Osterman. 1979. Late Quaternary extent of the West Antarctic ice sheet: new evidence from Ross Sea cores. Geology, 7(5), 249-253.

Kurtz, D. D., J. B. Anderson, K. M. Balshaw and M. L. Cole. 1979. Glacial marine sedimentation: relationship to the distribution of sediment geotechnical properties of high latitude continental margins. In 11th Annual Offshore Technology Conference, 30 April-3 May 1979, Houston, Texas. Proceedings. Houston, TX, Offshore Technology Conference, 683-688.

Maltman, A., ed. 1994. The geological deformation of sediements. London, Chapman and Hall.

Passchier, C.W. and R. A. J. Trouw. 1996. Micro-tectonics. Berlin and Heidelberg, Springer-Verlag.

Van der Meer, J. J. M. 1996. Micromorphology. In Menzies, J., ed. Past glacial environments, sediments, forms and techniques. Vol. 2. Glacial environments. Oxford, etc., Butterworth-Heinemann, 335-355

Van der Meer, J. J. M. 1993. Microscopic evidence of subglacial deformation. Quat. Sci. Rev., 12(7), 553-587.

Van der Wateren, F. M. 1995a. Identification of grounding episodes on the Ross Sea continental shelf using thin-section analyses of glacial and glaciomarine sediments. In VII International Symposium of Antarctic Earth Sciences, 10-15 September 1995, Siena, Italy. Abstracts. Siena, Museo Nazionale dell'Antartide, 388.

Van der Wateren, F. M. 1995b. Processes of glaciotectonism. In Menzies, J., ed. Modern glacial environments: processes, dynamics and sediments. Vol. 1. Glacial environments. Oxford, etc., Butterworth-Heinemann, 309-335.

Van der Wateren, F. M. 1995c. Structural geology and sedimentology of push moraines - processes of sift sediment deformation in a glacial environment and the distribution of glaciotectonic styles. Meded. Rijks Geol. Dienst 54.

Van der Wateren, F. M. In press. Structural geology and sedimentology of Saalian tills near Heiligenhafen, Germany. Quat. Sci. Rev. 